\title{
SISTEM INFORMASI AKUNTANSI PENGGAJIAN BERBASIS VB.NET PADA PT BANK PERKREDITAN RAKYAT (BPR) SANGGABUANA AGUNG KARAWANG
}

\author{
Jamilatus Sadiah $^{1}$, Indaryono ${ }^{2}$, Arif Maulana Yusuf ${ }^{3}$ \\ ${ }_{1,2,3}$ STMIK Rosma \\ Email : Jamilatus.sadiah@mhs.rosma.ac.id, indaryono@dsn.rosma.ac.id, arif@rosma.ac.id
}

\begin{abstract}
The payroll system is an important function that is the responsibility of Human Resources Management. Its main function is to provide compensation to employees in the form of salary in exchange for their contribution to the organization / agency. Payroll is one of the processes in an organization that is vulnerable to problems. Slow data processing can result in slow presentation of slow report making so that it is also possible to delay payment of salaries to employees. Plus if something goes wrong making salary calculations inaccurate. This makes the payroll system needs to be supported by a good information system. The research methodology used by the author in this research is the System Development Life Sycle (SDLC) Waterfall method. The development of research methodology has several sequential stages, namely: planning (modeling), modeling (modeling), construction (construction), and the delivery of the system to the customers / users (deployment). Based on the problems found, The author proposes to PT Bank Perkreditan Rakyat (BPR) Sanggabuana Agung Karawang to use VB.Net, it is expected that with the proposed system can improve Payroll problems that occur at PT Bank Perkreditan Rakyat (BPR) Sanggabuana Agung. Based on this research, the existence of a computerized employee payroll calculation system is expected to become a system that is useful for the development of the company in the future, and it is hoped that it can fix the problem and can also facilitate the calculation of payroll.
\end{abstract}

Keywords : Accountimg Informastion System, Payroll, VB.Net Programming

\begin{abstract}
Abstrak
Sistem penggajian merupakan fungsi penting yang menjadi tanggung jawab Manajemen Sumber Daya Manusia (SDM). Fungsi utamanya adalah untuk memberikan kompensasi kepada karyawan dalam bentuk gaji sebagai ganti kontribusi mereka terhadap organisasi/instansi. Penggajian merupakan salah satu proses dalam organisasi yang rentan terhadap masalah. Pengolahan data yang lambat dapat mengakibatkan lambatnya penyajian pembuatan laporan lambat sehingga dimungkinkan pula terjadi keterlambatan pembayaran gaji terhadap karyawan. Ditambah lagi jika terjadi kesalahan membuat perhitungan gaji menjadi tidak akurat. Hal ini menjadikan sistem penggajian perlu didukung oleh sistem informasi yang baik. Metodologi Penelitian yang digunakan penulis dalam penelitian ini yaitu metode System Development Life Sycle (SDLC) Waterfall. Pengembangan metodologi penelitian memiliki beberapa tahapan yang berurut yaitu: perencanaan (planning), permodelan (modeling), konstruksi (construction), serta penyerahan sistem ke para pelanggan/pengguna (deployment). Berdasarkan permasalahan yang ditemukan, Penulis mengusulkan kepada PT Bank Perkreditan Rakyat (BPR) Sanggabuana Agung Karawang untuk menggunakan VB.Net, diharapkan dengan sistem yang diusulkan dapat memperbaiki permasalahan Penggajian yang terjadi pada PT Bank Perkreditan Rakyat (BPR) Sanggabuana Agung. Berdasarkan penelitian ini, dengan adanya sistem perhitungan penggajian karyawan yang terkomputerisasi diharapkan nantinya akan menjadi suatu sistem yang berguna bagi perkembangan perusahaan dimasa yang akan datang, dan diharapkan mampu memperbaiki permasalahan juga dapat memudahkan dalam perhitungan penggajiannya.
\end{abstract}

Kata Kunci: Sistem Informasi Akuntansi, Penggajian, Pemrograman VB.Net 


\author{
Article History: \\ Accepted 4, Januari, 2021

\section{Corresponding Author:} \\ Nama Penulis, Indaryono \\ Departemen, STMIK Rosma \\ Instansi, STMIK Rosma \\ Alamat. Jl. Kertabumi No.62 Karawang Barat 41311 Karawang, Jawa Barat. \\ Email Penulis. indaryono@dsn.rosma.ac.id
}

\section{Pendahuluan}

Era globalisasi sekarang ini perusahaan dituntut untuk lebih Efisien, dan ekonomis dalam menentukan besarnya biaya operasional perusahaan, karena faktor ini adalah salah satu yang terpenting untuk menghadapi persaingan yang senakin ketat dengan perusahaan lain. Peran dari sistem informasi terhadap kemajuan organisasi sudah tidak diragukan lagi. Dengan dukungan sistem informasi yang baik maka sebuah perusahaan akan memiliki berbagai keunggulan kompetitif sehingga mampu bersaing dengan perusahaan lain. Informasi adalah data yang sudah mengalami pemrosesan sedemikian rupa sehingga dapat digunakan oleh penggunanya dalam membuat keputusan.

Setiap perusahaan membutuhkan banyak faktor untuk dapat menjalankan usahanya dengan sempurna. Faktor tenaga manusia dalam hal ini adalah salah satu faktor penting yang harus dimiliki oleh setiap perusahaan yang akan menjalankan usahanya. Karyawan merupakan orang pribadi yang dipekerjakan dalam perusahaan (pemberi kerja) yang melakukan pekerjaan berdasarkan suatu perjanjian kerja baik tertulis maupun tidak tertulis. Peran serta karyawan dalam melaksanakan tugasnya sangat mendukung pencapaian tujuan perusahaan. Untuk pencapaian tujuan perusahaan dibutuhkan adanya balas jasa atau bayaran yang sesuai bagi karyawan yang dapat menjadi salah satu usaha untuk memacu kinerja karyawan. Begitu pula dengan penggajian/gaji, yang dalam hal ini pengertian Gaji adalah salah satu hal yang penting bagi setiap karyawan yang bekerja dalam suatu perusahaan, karena dengan gaji yang diperoleh seseorang dapat memenuhi kebutuhan hidupnya. Beberapa pengertian tentang gaji atau Balas jasa yang biasanya diberikan oleh Perusahaan yaitu berupa gaji.

Akuntansi penggajian juga merupakan salah satu hal yang penting bagi suatu perusahaan karena merupakan faktor yang menentukan kinerja karyawan, penggajian merupakan bagian yang harus mendapat perhatian besar, karena selain biaya terbesar dalam biaya operasi perusahaan, juga karena karyawan sangat sensitif terhadap kesalahan yang terjadi dalam penggajian atau hal-hal yang tidak wajar yang berkaitan dengan penggajian. Melihat hal tersebut, maka diperlukan suatu sistem informasi akuntansi penggajian yang baik agar menghasilkan informasi penggajian yang cepat dan akurat.

PT Bank Perkreditan Rakyat (BPR) Sanggabuana Agung Karawang merupakan salah satu perusahaaan yang bergerak dibidang jasa keuangan meliputi tabungan, deposito, serta peminjaman kredit. PT BPR Sanggabuana Agung didirikan pada tahun 1971 yang sekarang berlokasi di Jl. Kertabumi No. 38, Kel. Karawang Kulon, Kec. Karawang Barat, Karawang 41311. Dalam pemberian gaji untuk karyawan berupa gaji bulanan, dimana dalam sistem penggajian pada PT BPR Sanggabuana Agung masih menggunakan Microsoft Excel, sehingga sering terjadinya kesalahan pengetikan ataupun perhitungan gaji untuk karyawan, jadi jumlah gaji yang didapat oleh karyawan sering tidak sesuai. 
Berdasarkan permasalahan diatas, penulis tertarik untuk merancang program perhitungan penggajian karyawang pada PT BPR Sanggabuana Agung berbasis Vb.net. Dengan adanya sistem perhitungan penggajian karyawan yang terkomputerisasi diharapkan nantinya akan menjadi suatu sistem yang berguna bagi perkembangan perusahaan dimasa yang akan datang, dan diharapkan mampu memperbaiki permasalahan juga dapat memudahkan dalam perhitungan penggajian untuk karyawan dan laporannya dapat digunakan sebagai dasar dalam pengambilan keputusan oleh pihak terkait.

Adapun Permasalahan yang ditemukan pada PT Bank Perkreditan Rakyat (BPR) Sanggabuana Agung Karawang adalah sebagai berikut :

1. Perhitungan gaji karyawan yang masih menggunakan Microsoft Excel.

2. Terkadang terjadi kesalahan perhitungan jumlah gaji karyawan.

3. Terjadi salah perhitungan Pph 21, dan gaji sering tidak sesuai.

Adapun batasan masalah yang diambil supaya dapat dilakukan secara lebih mendalam yaitu Identifikasi prosedur penggajian karyawan pada PT Bank Perkreditan Rakyat (BPR) Karawang, Mengidentifkasi pembuatan laporan penggajian berikut $\mathrm{PPh}$ pasal 21 beserta potongan dan tunjangan lainnya, Membuat sistem yang terkomputerisasi mengenai perhitungan gaji karyawan berbasi Vb.net berikut perhitungan pajak $\mathrm{PPh}$ pasal 21 pada PT Bank Perkreditan Rakyat (BPR) Sanggabuana Agung Karawang.

Pada penelitian ini tentu memiliki suatu tujuan yaitu :

1. Merancang aplikasi perhitungan penggajian berbasis Vb.net pada PT Bank Perkreditan Rakyat (BPR) Sanggabuana Agung Karawang.
2. Menyajikan informasi perhitungan penggajian karyawan yang cepat dan akurat

\section{Dasar Teori}

\subsection{Akuntansi}

Menurut Anastasia Diana dan Lilis Setiawati, "akuntansi merupakan proses mengidentifikasi, mengukur, mencatat dan mengkomunikaikan peristiwa peristiwa ekonomi dari suatu organisasi (bisnis maupun non bisnis) kepada pihak-pihak yang berkepentingan dengan informasi bisnis tersebut (pengguna informasi)"'[1].

Menurut Azhar Susanto, "akuntansi adalah bahasa bisnis, setiap organisasi menggunakannya sebagai bahasa komunikasi saat berbisnis, seperti saat terjadi penukaran barang dengan sejumlah uang dalam akuntansi diistilahkan sebagai menjual atau membeli"'[2].

Berdasarkan definisi diatas dapat disimpulkan bahwa akuntansi tidak hanya dibutuhkan untuk mengidentifikasi dan mencatat peristiwa ekonomi dan bisnis yan terjadi tetapi harus dapat mengkomunikasikan kepada pihak-pihak yang memiliki kepentingan.

\subsection{Sistem Informasi Akuntansi}

Krismiaji, "Sistem informasi akuntansi adalah sebuah sistem yang memproses data dan transaksi guna menghasilkan informasi yang bermanfaat untuk merencanakan, mengendalikan, dan mengoperasikan bisnis"[3].

Menurut Zaki Baridwan, "system informasi akuntansi adalah suatu komponen suatu organisasi yang mengumpulkan, menghasilkan, mengolah, menganalisa, serta mengkomunikaikan informasi financial dan pengambilan keputusan yang relevan kepada pihak diluar perusahaan (seperti kantor pajak, investor) dan pihak intern (terutama manajemen)"[4].

Jurnal Interkom: Jurnal Publikasi Ilmiah Bidang Teknologi Informasi dan Komunikasi

Volume 15 Nomor 04 Bulan Januari - Tahun 2021 
Kesimpulan dari dua pengertian diatas adalah Sistem Informasi Akuntansi merupakan subsistem dari Sistem Informasi yaitu untuk mengolah atau memproses serta menganalisa data transaksi keuangan guna menghasilkan informasi berupa laporan keuangan yang nanti nya digunkan sebagai pengambilan keputusan.

\subsection{Penggajian}

Menurut Moch Tofik, "penggajian yaitu semua gaji yang dibayarkan perusahaan kepada karyawannya. Para manajer, pegawai administrasi, dan pegawai penjualan, biasanya mendapat gaji dari perusahaan yang jumlahnya tetap. Tarif gaji biasanya dinyatakan dalam gaji perbulan"[5].

Menurut amsyah, "penggajian adalah proses saat karyawan menerima gaji dan upah"[6].

Kedua definisi diatas dapat disimpulkan Penggajian adalah pemberian atau balasan dari perusahaan kepada semua pegawai atas jasa yang telah diberikan kepada perusahaan dan gaji biasa diberikan dan diterima oleh karyawan tiap bulan

\subsection{Pembayaran BPJS dan Potongan lainnya}

1. Jaminan Kecelakaan Kerja (JKK) Jaminan Kecelakaan Kerja (JKK) Jaminan kecelakaan kerja adalah kompensasi dan rehabilitasi bagi tenaga kerja yang mengalami kecelakaan saat mulai berangkat kerja sampai tiba kembali dirumah atau menderita penyakit yang berhubungan dengan pekerjaan.

2. Jaminan Kematian (JKM)

Jaminan Kematian (JK) Jaminan kematian diperuntukan kepada ahli waris dari peserta program BPJS Ketanakerjaan yang meninggal bukan karena kecelakaan kerja.
Pengusaha wajib menanggung iuran program Jaminan Kematian sebesar $0,3 \%$ dari gaji atau upah.

3. Jaminan Kesehatan

(BPJS

Kesehatan)

Jaminan Kesehatan (JKes/BPJS

Kesehatan) berlaku sejak Juli 2015 adalah program BPJS kesehatan yang diikuti wajib pajak. Tarif iurannya adalah 5\% dari gaji per bulan yaitu sebanyak $4 \%$ dibayar oleh pemberi kerja, dan $1 \%$ oleh pegawai. Gaji atau upah yang digunakan sebagai dasar perhitungan iuran Jaminan Kesehatan terdiri dari gaji atau upah pokok dan tunjangan tetap. Batas paling tinggi gaji atau upah per bulan yang digunakan sebagai dasar perhitungan iuran adalah 2 kali PTKP dengan status kawin dengan 1 anak. Untuk keluarga lainnya, yaitu terdiri dari anak keempat dan seterusnya, orang tua dan mertua, besarnya iuran adalah $1 \%$ per orang dari gaji/upah.

4. Pengurangan Penghasilan Bruto

Penguran Penghasilan Bruto Pengurangan Penghasilan Bruto adalah biaya-biaya yang dapat mengurangi penghasilan bruto atau kotor.

5. Biaya Jabatan

Biaya Jabatan adalah biaya yang diasumsikan perpajakan bahwa sebagai pegawai pasti memiliki pengeluaran (biaya) selama setehun yang berhubungan dengan pekerjaannya. Karena itu ditetapkan dalam Peraturan Direktur Jenderal Pajak No. PER-16/PJ/2016 bahwa biaya jabatan adalah sebesar 5\% dari penghasilan bruto setahun dan setinggi-tingginya $\mathrm{Rp}$ 500.00,sebulan atau Rp 6 juta setahun. Dari

Jurnal Interkom: Jurnal Publikasi Ilmiah Bidang Teknologi Informasi dan Komunikasi 
staf biasa sampai direktur berhak mendapat pengurang penghasilan bruto.

\subsection{SQL Server 2008}

Menurut Wahana Kompute, " $S Q L$ Server 2008 adalah sebuah terobosan baru di Microsoft dalam bidang database. $S Q L$ Server adalah sebuah DBMS (Database Management System) yang dibuat oleh Microsoft untuk ikut berkecimpung dalam persaingan dunia pengolahan data menyusul pendahulunya seperti $I B M$ dan Oracle. SQL Server 2008 dibuat pada saat kemajuan dalam bidang hardware sedemikian pesat. Oleh karena itu sudah dapat dipastikan bahwa SQL Server 2008 membawa beberapa terobosan dalam bidang pengolahan dan penyimpanan data"[7].

\subsection{Visual Basic Net}

Menurut Hidayatullah mengatakan bahwa, "Visual Basic.NET adalah Visual Basic yang direkayasa kembali untuk digunakan pada platform .NET sehingga aplikasi yang dibuat menggunakan Visual Basic.NET dapat berjalan pada sistem komputer apapun, dan dapat mengambil data dari server dengan tipe apapun asalkan terinstal .NET Framework"[8].

\subsection{Microsoft Visual Studio 2010}

Microsoft Visual Studio 2010 merupakan kelanjutan dari Microsoft Visual Studio sebelumnya, yaitu Visual Studio .Net Framework versi 1.0. Pemrograman Microsoft Visual Studio. Net 2010 adalah sebuah platform untuk membangun, menjalankan, dan meningkatkan generasi lanjut dari aplikasi terdistribusi[9].

Net Framework merupakan platform terbaru untuk pemrograman aplikasi window dari Microsoft dalam upaya meningkatkan produktivitas pembuatan sebuah program aplikasi dan memungkinkan terbukanya peluang untuk menjalankan program pada multi sistem operasi serta dapat memperluas pengembangan aplikasi Client-Server.

Visual Studio 2010 merupakan aplikasi yang menggunakan Net Framework 3.5. Beberapa bagian dasar visual basic 2010 terdiri dari Menu, Toolbox, Form, Solution Explorer, Properties, Error List dan lain sebagainya. (Sofyan Maulana, 2015:3).

Berikut merupakan bagian-bagian dasar dari visual Studio 2010, di antaranya:

\section{Menu}

Menu pada Visual Studio 2010 terdapat File, Edit, View dan seterusnya. Sama halnya dengan Microsoft Word yang biasa digunakan untuk menyimpan dokumen atau menambahkan beberapa setingan dokumen, maka hal ini juga sama saja dengan menu pada Visual Basic 2008 dapat menambahkan Form, menjalankan atau run program serta menyimpan hasil project Visual Basic 2008 itu sendiri.

\section{Toolbox}

Toolbox biasanya digunakan untuk menambahkan Component pada Form, yang biasa di gunakan untuk kebutuhan dari Form itu sendiri.

3. Form

Form adalah lembar kerja yang akan gunakan untuk membuat aplikasi, juga dapat menambahkan beberapa component dengan memilih ToolBox, sehingga Form dapat bekerja seperti yang di inginkan

\section{Solution Explorer}

Solution Explorer di gunakan untuk melihat beberapa component yangditambahkan dalam suatu project, dapat berupa Form, Module dan lainsebagainya. Solution Explorer juga dapat digunakan untuk melihat code program yang terdapat pada masing-masing component yang ditambahkandalam suatu project.

\section{Properties Windows}

Properties Windows di gunakan untuk melihat properties sebuah component yang ditambahkan pada sebuah Form. Dapat digunakan juga untuk merubahbeberapa setingan sebuah component yang telah ditambahkan pada sebuah Form. 


\section{Error List}

Error List akan menunjukkan seberapa banyak nya pesan error pada saat menuliskan atau mengetik program secara real time. Jika memang terdapat error atau kesalahan dalam penginputan sebuah script program, maka pesan error tersebut akan langsung tampil di menu Error List.

\section{Metodologi Penelitian}

Merancang aplikasi ini penulis menggunakan metodologi Waterfall. Metode air terjun atau yang sering disebut metode waterfall sering dinamakan siklus hidup klasik (classic life cycle), dimana hal ini menggambarkan pendekatan yang sistematis dan juga berurutan pada pengembangan perangkat lunak, dimulai dengan spesifikasi kebutuhan pengguna lalu berlanjut melalui tahapan-tahapan perencanaan (planning), permodelan (modeling), konstruksi (construction), serta penyerahan sistem ke para pelanggan/pengguna (deployment), yang diakhiri dengan dukungan pada perangkat lunak lengkap yang dihasilkan (Pressman, 2012).

Berikut ini contoh gambar ilustrasi tahapan pengembangan sistem Waterfall :

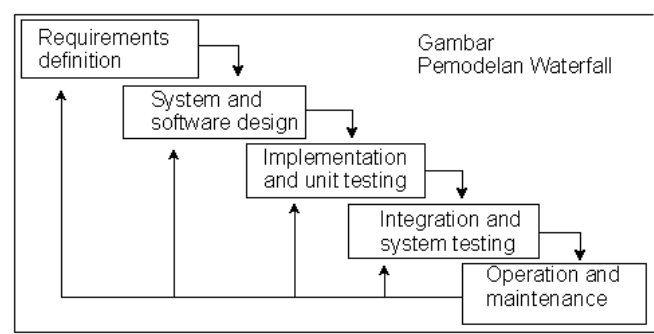

Gambar 1. Contoh Tahapan Waterfall

a. Analisis Kebutuhan (Requirement Analisis)

Tahap ini pengembang sistem diperlukan komunikasi yang bertujuan untuk memahami perangkat lunak yang diharapkan oleh pengguna dan batasan perangkat lunak tersebut. Informasi ini biasanya dapat diperoleh melalui wawancara, diskusi atau survei langsung. Informasi dianalisis untuk mendapatkan data yang dibutuhkan oleh pengguna. Dalam melakukan analisis kebutuhan, penulis melakukan langkah-langkah diantaranya :

1) Wawancara

Dalam pengumpulan data yang diperlukan dalam pembahasan laporan tugas akhir penulis melakukan tanya jawab langsung kepada Ibu Diana Putri selaku bagian Accounting dan Bapak Rizky Tanaya Ikram selaku bagian Pejabat Eksskutif. Kepatuhan, Manajemen Risiko dan APU-PPT di PT Bank Perkreditan Rakyat (BPR) Sanggabuana Agung Karawang.

2) Observasi Lapangan

Untuk memahami sistem yang sedang berjalan penulis melakukan observasi secara langsung.

\section{3) Studi Pustaka}

Teknik pengumpulan data diperpustakaan dengan mengumpulkan atau menggunakan sumber-sumber tertulis yang bersumber pada buku-buku dan dokumendokumen yang berkaitan dengan masalah yang diteliti sebagai landasan teori.

b. Desain Sistem (System Design)

Target akhir tahapan ini adalah menghasilkan rancangan yang memenuhi kebutuhan yang ditentukan selama tahapan analisis sistem. Spesifikasi kebutuhan dari 
tahap sebelumnya akan dipelajari dalam fase ini dan desain sistem disiapkan. Desain Sistem membantu dalam menentukan perangkat keras (hardware) dan sistem persyaratan dan juga membantu dalam mendefinisikan arsitektur sistem secara keseluruhan. Metode perancangan yang akan digunakan penulis dalam menyusun tugas akhir ini adalah perancangan flow document, DFD (Data Flow Diagram), kamus data, ERD (Entity Relationship Diagram), dan pembanguna bagan terstruktur dengan rancangan masukan dan keluaran pada sistem yang sedang berjalan.

c. Penerapan (Implementation)

Pada tahap ini, sistem pertama kali dikembangkan di program kecil yang disebut unit, yang terintegrasi dalam tahap selanjutnya. Setiap unit dikembangkan dan diuji untuk fungsionalitas yang disebut sebagai unit testing.

d. Pengujian (Testing)

Seluruh unit yang dikembangkan dalam tahap implementasi diintegrasikan ke dalam sistem setelah pengujian yang dilakukan masing-masing unit. Setelah integrasi seluruh sistem diuji untuk mengecek setiap kegagalan maupun kesalahan.

e. Pemeliharaan (Maintenance)

Tahap akhir dalam metode waterfall ini adalah, perangkat lunak yang sudah jadi, dijalankan serta dilakukan pemeliharaan. Pemeliharaan termasuk dalam memperbaiki kesalahan yang tidak ditemukan pada langkah sebelumnya. Perbaikan implementasi unit sistem dan peningkatan jasa sistem sebagai kebutuhan baru.

\section{Hasil dan Pembahasan}

Bank Perkreditan Rakyat Sanggabuana Agung selanjutnya disebut "BPR SBA" pada awalnya merupakan sebuah Bank Pasar yang didirikan pada tahun 1971 dengan Izin Usaha Bank Pasar No.Ket010/DDK/II/4/72 dengan Nama PT. BANK PASAR SANGGABUANA berkedudukan di Jalan Raya Pasar Johar No. 15.

Pada hari Kamis tanggal 18 November 1971 dihadapan Notaris Raden Kosasih Sachri dengan dihadiri 6 saksi maka berdirilah Perseroan Terbatas "P.T. Bank Pasar Sanggabuana Agung" yang tertuang dalam Akta Notaris Nomor 9. Akta tersebut didaftarkan di Kepaniteraan Pengadilan Negeri Karawang No. 52/N/1978.

Berdasarkan Akta Notaris $r$ tersebut
Bank Pasar Sanggabuana Agung
memperoleh Persetujuan r untuk
melanjutkan usaha sebagai Bank Pasar,
dengan demikian kedudukan dan
keberadaan Bank Pasar Sanggabuana
Agung sebagai Lembaga Keuangan secara
hukum telah di akui oleh pemerintah dan
dilindungi undang-undang.
dilindungi undang-undang. 
Akta Pendirian PT. Bank Pasar Sanggabuana Agung tersebut mendapat persetujuan dari Departemen Kehakiman Republik Indonesia melalui Surat Keputusan Menteri Kehakiman Republik Indonesia tertanggal Agustus 1978 No. Y.A 5/202/9. Dan berdasarkan Anggaran Dasar Perseroan Nomor 36/N/II/2000 tanggal 16 Februari 2000, PT. Bank Pasar Sanggabuana Agung berubah nama menjadi PT. Bank Perkreditan Rakyat Sanggabuana Agung.

\subsection{Flow of Document Sistem yang Berjalan}

Adapun Flow Of Document sistem penggajian yang berjalan di PT Bank Pengkreditan Rakyat (BPR) Sanggabuana Agung seperti gambar berikut :

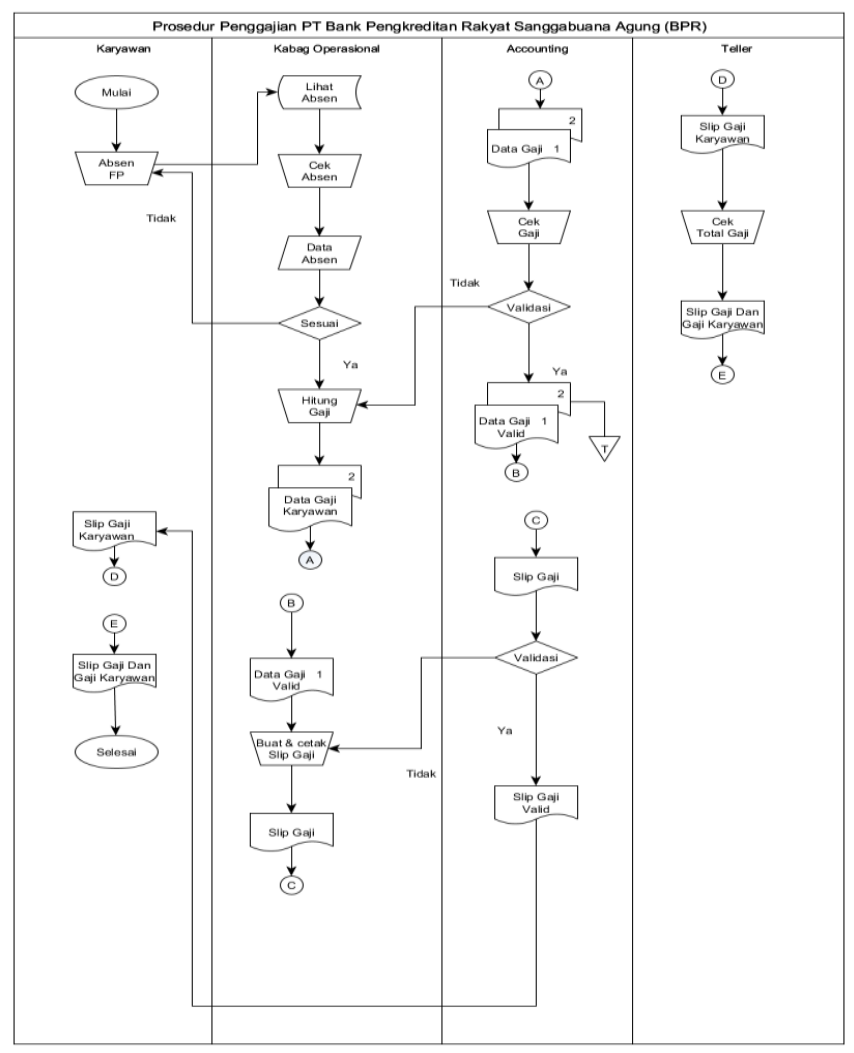

Gambar 2 Flow of document Penggajian Karyawan PT BPR SBA

4.2 Flow of Document Usulan

Berdasarkan permasalahan yang ditemukan, penulis mencoba membuat usulan prosedur yang baru yaitu sebagai berikut:

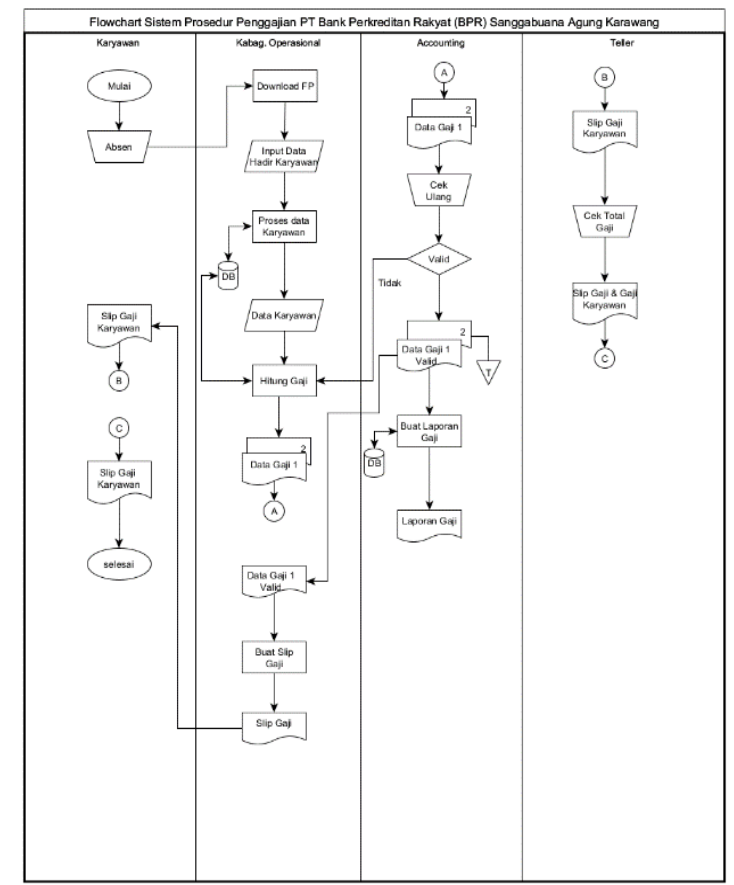

Gambar 3 Flow Of System Usulan penggajian PT BPR SBA

\subsection{Implementasi Sistem}

a. Form Start Up

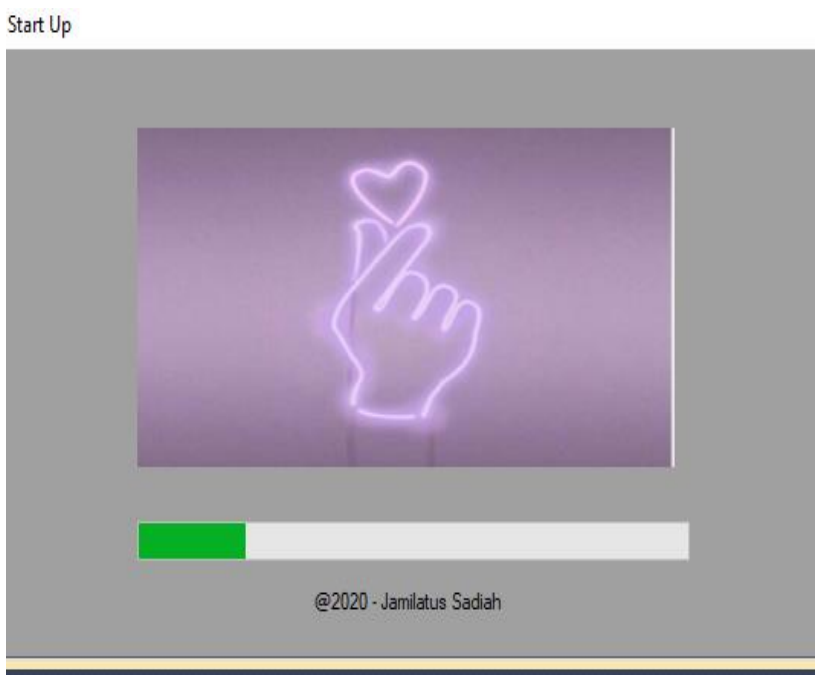

Gambar 4. Form Start Up 
b. Form Login

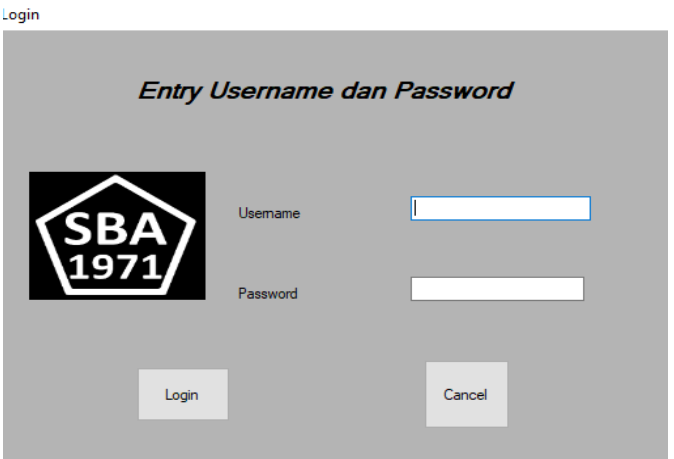

Gambar 5. Form Login

c. Form Menu Utama

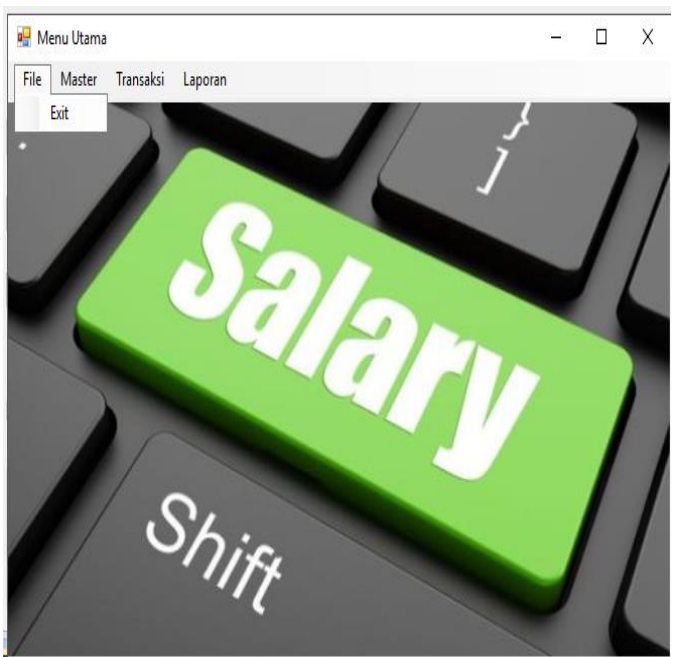

Gambar 6. Form Menu Utama

d. Form Data Karyawan

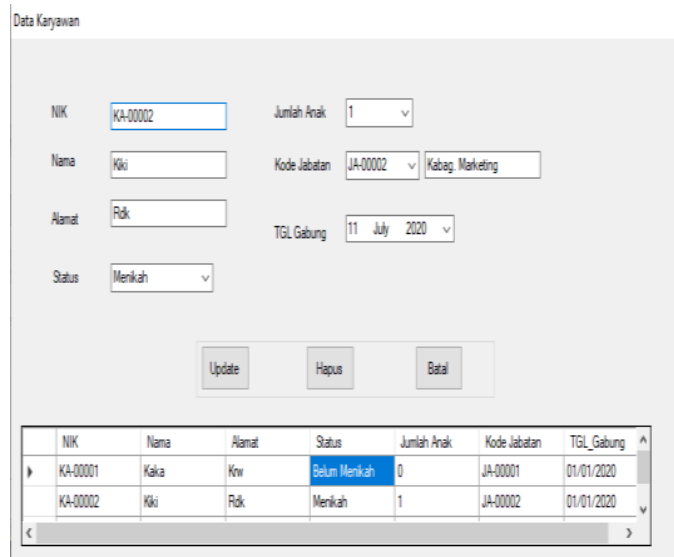

Gambar 7. Form Data Karyawan e. Form Jabatan

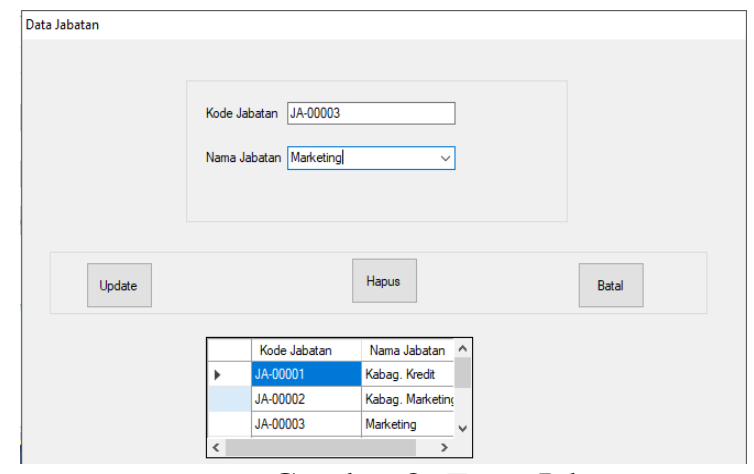

Gambar 8. Form Jabatan

f. Form Absensi

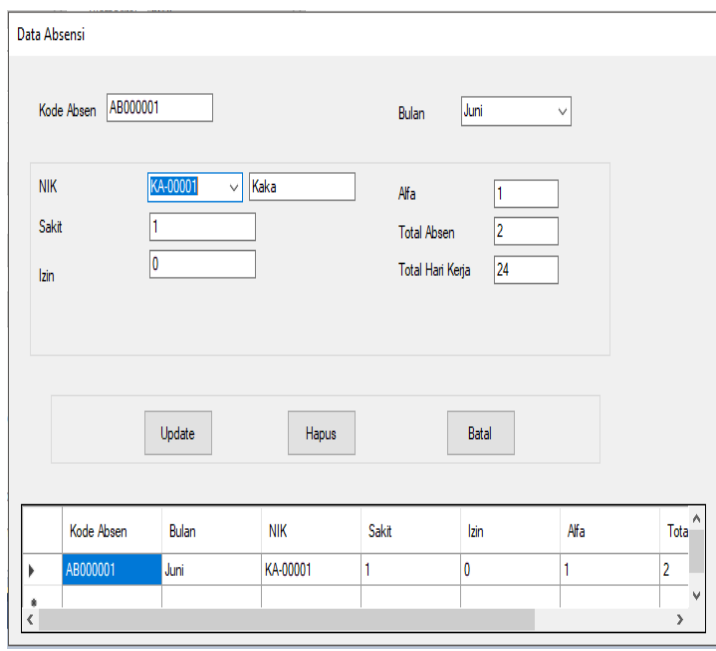

Gambar 9. Form Absensi

g. Form Perhitungan Gaji

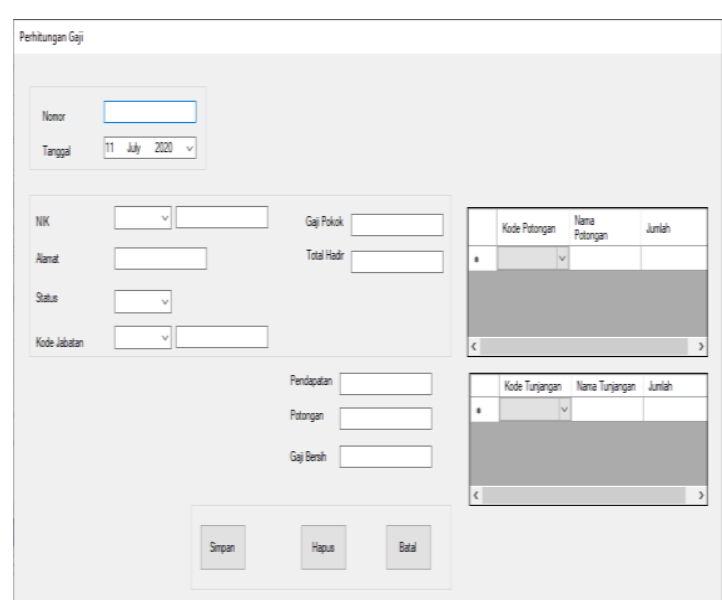

Gambar 10. Form Perhitungan Gaji

Jurnal Interkom: Jurnal Publikasi Ilmiah Bidang Teknologi Informasi dan Komunikasi 


\section{h. Form Cetak Slip}

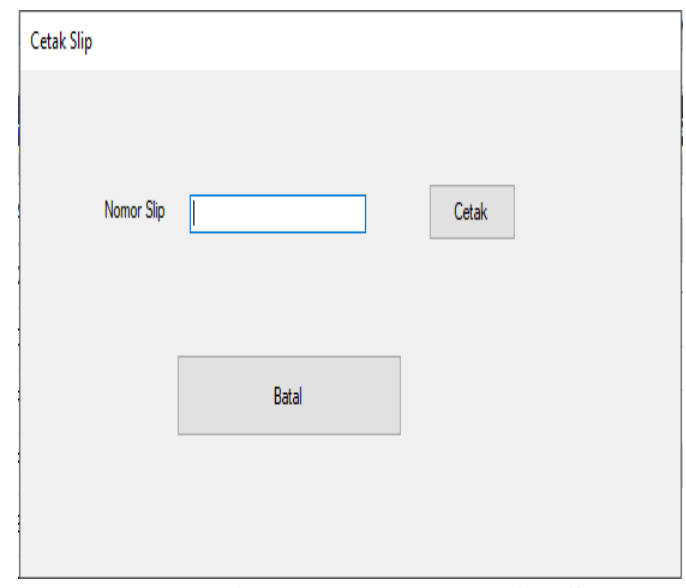

Gambar 11. Form Cetak Slip

i. Tampilan Laporan Total Gaji

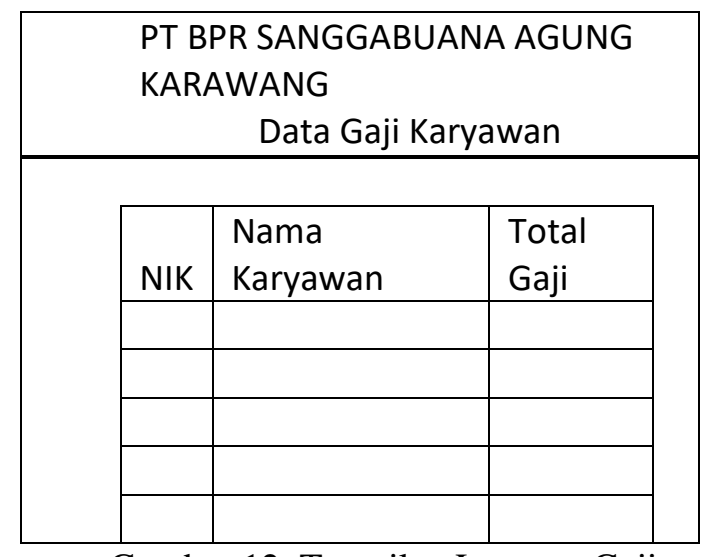

Gambar 12. Tampilan Laporan Gaji

\section{Penutup}

\subsection{Kesimpulan}

Berdasarkan identifikasi dan pembahasan yang telah diuraikan pada babbab sebelumnya yaitu laporan Tugas Akhir dengan judul Sistem Informasi Akuntansi Penggajian Berbasi Vb.Net pada PT Bank Perkreditan Rakyat (BPR) Sanggabuana Agung Karawang, maka penulis dapat mengambil kesimpulan sebagai berikut :

1. Penulis telah melakukan identifikasi pada saat observasi penelitian terhadap prosedur penggajian karyawan PT Bank Perkreditan Rakyat (BPR) Sanggabuana Agung Karawang yang saat ini masih menggunakan/ memanfaatkan Microsoft excel.

2. Penulis telah mengidentifikasi pada saat observasi penelitian terhadap pembuatan laporan penggajian berikut Pph pasal 21 beserta potongan dan tunjangan lainnya pada PT Bank Perkreditan Rakyat

(BPR)

Sanggabuana Agung Karawang yang saat ini masih menggunakan/memanfaatkan

Microsoft excel.

3. Penulis berdasarkan observasi penelitian dan membuat laporan tugas akhir telah membuat sistem perhitungan gaji karyawan serta perhitungan Pph pasal 21 berbasi Vb.Net.

\subsection{Saran}

Setelah mengambil kesimpulan mengenai penggajian pada PT Bank Perkreditan Rakyat (BPR) Sanggabuana Agung Karawang, maka penulis memberikan saran yang berhubungan dengan kegiatan penggajian. Adapun saran dari penulis adalah sebagai berikut :

1. Penulis menyarankan pada PT Bank Perkreditan Rakyat (BPR) Sanggabuana Agung Karawang berdasarkan hasil laporan tugas akhir bahwa untuk menghindari kesalahan pada proses pencatatan, perhitungan dan pelaporan penggajian sebaiknya harus menggunakan dan menerapkan sistem penggajian yang terkomputerisasi. Sebaiknya untuk menghindari kesalahan yang terjadi pada proses pencatatan, perhitungan dan pelaporan penggajian sebaiknya mulai menerapkan sistem penggajian terkomputerisasi, khususnya untuk mengurangi masalah yang sekarang terdapat pada sistem yang sudah berjalan. 
2. Pelaksanaan sistem diharapkan berjalan dengan baik, jadi perusahaan bisa melakukan sosialisasi dan pelatihan terlebih dahulu pada karyawan sehingga diharapkan bisa beradaptasi dengan baik dengan sistem terkomputerisasi dan melakukan uji coba terlebih dahulu selama jangka waktu yang ditentukan agar pengguna sistem dapat lebih mengerti tentang jalannya sistem yang baru sebelum benar-benar diterapkan.

3. Diharapkan dengan sistem yang diusulkan dapat meminimalisir kesalahan-kesalahan yang terjadi dan mempermudah pekerjaan karyawan yang bersangkutan.

\section{Daftar Pustaka}

[1] Anastasia Diana, Lilis Setiawati. 2011. Sistem Informasi Akuntansi, Perancangan, Prosedur dan Penerapan. Edisi 1. Yogyakarta: Andi Yogyakarta.

[2] Azhar, Susanto. 2017. Sistem Informasi Akuntansi. Cetakan pertama. Lingga Jaya. Bandung

[3] Krismiaji, 2015, Sistem Informasi Akuntansi, Unit Penerbit, Yogyakarta.

[4] Baridwan, Zaki. 2013. Sistem Informasi Akuntansi, edisi kedua. Yogyakarta: BPFE.

[5] Moch. Tofik. 2010 Panduan Praktisi Membuat Apliukasi Penggajian Dengan Excel 2007, Jakarta:Penerbit Mediakita.

[6] Amsyah, Zulkifli. 2005, Manajemen Sistem Informasi. Jakarta: PT Gramedia Pustaka

Utama.
[7] Wahana Komputer. 2010. Panduan Belajar MySQL Database Server. Jakarta: Mediakita.

[8] Hidayatullah, Priyanto. 2014. Visual Basic .NET.Edisi Revisi. Bandung:Informatika

[9] Darmayuda, Ketut, 2010, Pemprograman Aplikasi Database dengan Microsoft Visual Basic .NET 2008, Informatika Bandung, Bandung. 